\title{
Effect of trolox added to freezing extenders over goat and ram spermatozoa
}

\author{
Efeito da adição de trolox em diluentes de congelação sobre o sêmen caprino e ovino \\ Efecto de la adición de trolox en los diluyentes de congelación en el semen de cabra y oveja
}

Received: 04/08/2021 | Reviewed: 04/15/2021 | Accept: 04/16/2021 | Published: 04/29/2021

Lúcia Cristina Pereira Arruda

ORCID: https://orcid.org/0000-0002-5732-9777

Universidade Federal Rural de Pernambuco, Brazil

E-mail: luciacpa@hotmail.com

Girliane Regina da Silva

ORCID: https://orcid.org/0000-0002-5843-4405

Universidade Federal Rural de Pernambuco, Brazil

E-mail: girlianeregina@gmail.com

André Mariano Batista

ORCID: https://orcid.org/0000-0003-1904-0531

Universidade Federal Rural de Pernambuco, Brazil

E-mail: marianopq@gmail.com

Ellen Cordeiro Bento da Silva

ORCID: https://orcid.org/0000-0001-8935-6553

Universidade Federal Rural de Pernambuco, Brazil

E-mail: silvaecb@gmail.com

Helder Melo de Souza

ORCID: https://orcid.org/0000-0001-9076-9232

Universidade Federal Rural de Pernambuco, Brazil

E-mail: heldermsouza@ hotmail.com

Giovanna Isabella de Souza Couto

ORCID: https://orcid.org/0000-0002-5299-9552

Universidade Federal Rural de Pernambuco, Brazil

E-mail: giovanna1couto@hotmail.com

Tânia Maria Sarmento Silva

ORCID: https://orcid.org/0000-0003-1887-2598

Universidade Federal Rural de Pernambuco, Brazil

E-mail: sarmentosilva@gmail.com

Maria Madalena Pessoa Guerra

ORCID: https://orcid.org/0000-0002-5373-4062

Universidade Federal Rural de Pernambuco, Brazil

E-mail: mmpguerra@gmail.com

\begin{abstract}
Semen cryopreservation is responsible for decrease the gamete fertility, due to structural and functional damages. Among the various causes, oxidative stress, resulting from the higher generation of reactive oxygen species (ROS), has been attributed to affect semen quality. Thus, it was objectified evaluate the effect of Trolox on ram and goat sperm, subjected to freezing. Semen pools of goat $(n=5)$ and ram $(n=6)$ were diluted in skimmed milk (7\% glycerol) or Tris-egg yolk (5\% glycerol) extender, respectively, added or not of Trolox $(0,20$ or $40 \mu \mathrm{M} / \mathrm{ml})$ and frozen. After thawing $\left(37^{\circ} \mathrm{C} / 30 \mathrm{~s}\right)$, aliquots of semen were evaluated for lipid peroxidation by high performance liquid chromatography, coupled with a photodiode array detector (HPLC-DAD), and flow cytometry (C11BODIPY581/591), besides of plasma membrane and acrosome integrity by fluorescence microscopy, and sperm kinetics by computerized sperm analysis (CASA). The antioxidant treatment with Trolox did not determine significant effects ( $>0.05$ ) on lipid peroxidation, plasma membrane integrity, acrosomal integrity and on the kinetic parameters evaluated. Thus, it is concluded that Trolox $(20$ or $40 \mu \mathrm{M})$ did not have a protective or deleterious effect on goats and ram sperm, submitted to freezing.
\end{abstract}

Keywords: Antioxidants; Lipoperoxidation; Ruminant; Semen; Vitamin E.

\section{Resumo}

O processo de criopreservação do sêmen ocasiona a diminuição da fertilidade dos gametas, devido a danos estruturais e funcionais. Entre as várias causas, o estresse oxidativo, resultante da maior geração de espécies reativas de oxigênio (ROS), tem sido atribuído por afetar a qualidade seminal. Assim, objetivou-se avaliar o efeito do Trolox sobre os espermatozoides caprinos e ovinos submetidos à congelação. Pools de sêmen caprino $(n=5)$ e ovino $(n=6)$ foram diluídos em diluidores a base de leite desnatado (Glicerol 7\%) ou Tris-gema de ovo (Glicerol 5\%), respectivamente, adicionados ou não de Trolox $\left(0,20\right.$ ou $40 \mu \mathrm{M} / \mathrm{mL}$ ), e congelados. Após descongelação ( $\left.37^{\circ} \mathrm{C} / 30 \mathrm{~s}\right)$, alíquotas foram avaliadas quanto à peroxidação lipídica, por cromatografia líquida de alta performance acoplada a detector de arranjo 
de diodos (HPLC-DAD) e por citometria de fluxo (C11-BODIPY581/591), à integridade de membrana plasmática e acrossomal, por microscopia fluorescente, e à cinética espermática, pelo sistema computadorizado de análise espermáticas (CASA). O tratamento antioxidante com Trolox não determinou efeitos significativos ( $\mathrm{p}>0,05)$ sobre a peroxidação lipídica, integridade de membranas plasmática e acrossomal e parâmetros cinéticos avaliados. Assim, conclui-se que o Trolox ( $20 \mathrm{ou} 40 \mu \mathrm{M})$ não apresenta efeito protetor ou nocivo sobre os espermatozoides caprinos e ovinos submetidos à congelação.

Palavras-chave: Antioxidantes; Lipoperoxidação; Ruminante; Sêmen; Vitamina E.

\section{Resumen}

El proceso de criopreservación del semen provoca una disminución de la fertilidad de los gametos debido a daños estructurales y funcionales. Entre las diversas causas, el estrés oxidativo, resultante de la mayor generación de especies reactivas de oxígeno (ROS), ha sido atribuido por afectar a la calidad seminal. Así, se pretendía evaluar el efecto de Trolox en los espermatozoides de cabra y oveja sometidos a congelación. Se diluyeron pooles de semen de cabras $(n=5)$ y ovejas $(n=6)$ en diluyentes a base de leche desnatada (Glicerol 7\%) o de Tris-gema de huevo (Glicerol $5 \%)$, respectivamente, añadidos o no de Trolox $(0,20$ o $40 \mu \mathrm{M} / \mathrm{mL})$, y sometido a congelación. Tras la descongelación $\left(37^{\circ} \mathrm{C} / 30 \mathrm{~s}\right)$, se evaluó la peroxidación lipídica de las alícuotas, mediante cromatografía líquida de alto rendimiento acoplada a un detector de matriz de diodos (HPLC-DAD) y también mediante citometría de flujo (C11-BODIPY581/591), la integridad de las membranas plasmáticas y acrosómicas, por médio de microscopía de fluorescencia, y la cinética de los espermatozoides, mediante el sistema computarizado de análisis de esperma (CASA). El tratamiento antioxidante con Trolox no determinó efectos significativos ( $p>0,05)$ sobre la peroxidación lipídica, la integridad de las membranas plasmáticas y acrosomales y los parámetros cinéticos evaluados. Así pues, se concluye que Trolox (20 o $40 \mu \mathrm{M})$ no presenta un efecto protector o perjudicial sobre los espermatozoides de cabra y oveja sometidos a congelación.

Palabras clave: Antioxidantes; Lipoperoxidación; Rumiantes; Semen; Vitamina E.

\section{Introduction}

The semen cryopreservation process determines cellular changes that contribute to the fertility reduction, when compared to fresh semen (Bicudo et al., 2007), being the plasma membrane one of the most affected structures (Castro et al., 2016). These changes in sperm cells are associated with the biochemical, osmotic, thermal and mechanical stresses, which are seen at different stages of freezing process (Gangawar et al., 2016). Additionally, reactive oxygen species (ROS) can play a negative impact on sperm integrity during the cryopreservation, which have as main substrate the polyunsaturated fatty acids, mainly present in the cell membranes (Colagar et al., 2013; Castro et al., 2016).

The ROS reaction with cellular polyunsaturated fatty acids (PUFA), start a chain process known as lipid peroxidation (LPO) (Bollwein \& Bittner, 2018). Because of the sperm damages, caused by ROS, occur a reduction in semen quality, that includes abnormalities in the intermediate piece, motility decrease, loss of the sperm capacity to perform the acrosome reaction, apoptosis acceleration and fertility impairment (Aitken et al., 1993). Thus, the evaluation and control of the oxidative status and antioxidant defenses system is important as an indicator of the male fertility, especially (Colagar et al., 2013).

Trying to minimize the sperm damage, caused by LPO, antioxidants have been tested (Solihati et al., 2018; Ugur et al., 2019). Among these, vitamin "E" and its hydro-soluble analog, Trolox, stands out. It is indicated as an excellent protector against lipid peroxidation and has been successfully tested in ram sperm (Maia et al., 2010; Sicherle et al., 2011; Silva et al, 2013). Sperm from humans (Taylor et al., 2009; Minaei et al., 2012), ram (Silva et al., 2013) and boar (Pena et al., 2003; Zanella et al., 2016), cryopreserved with Trolox supplementation, present better motility, that do of this agent an important ally to the semen conservation.

Based on the exposed above, was objected in this study evaluated the Trolox effect on goat and ram cryopreserved sperm, through the lipid peroxidation, membranes integrity and kinematics evaluation. 


\section{Methodology}

All reagents used to the scientific research were purchased from Sigma-Aldrich (St. Louis, USA), with the exception of 2-tiobarbituric acid (MERCK, Darmstadt, Germany), potassium hydroxide (VETEC, Rio de Janeiro, Brazil), sodium hydroxide (NUCLEAR, São Paulo, Brazil) and methanol (CARLOS ERBA, Val de Reuil, France). Moreover, national and institutional guidelines for the care and use of animals were followed, having been the animal procedures approved by the Ethics Committee on the Use of Animals (UFRPE Process Number CEUA / UFRPE 014/2012).

To perform the study around the Trolox effect on goat and ram cryopreserved sperm, were used five goats and six ram sexually mature, with a fertility history and handled intensively. The animals were feed with Tifton hay and 400 g/day of commercial concentrated, besides water and mineral salt ad libitum. From these, ejaculated were obtained by artificial vagina, in presence of a female as a dummy (Oliveira et al., 2013), in alternate days, totaling five ejaculated per goats and six per ram (25 and 36 ejaculated, respectively). The semen samples were subjectively evaluated macroscopic and microscopically, under a phase contrast microscope (Olympus, Japan; 100x), and only ejaculated with motility $\geq 70 \%$ (CBRA, 2013) were approved and destined to form the semen pools.

Each experimental repetition corresponded to a semen pool, formed by 5 goats or 6 ram ejaculated, totaling 5 and 6 pools per experiment, respectively. It was done to eliminate the individual variation (Bucak et al., 2008). The minimum requirements to freeze the seminal pool were: volume $\geq 3.0 \mathrm{~mL}$, motility $\geq 70 \%$ and sperm concentration $\geq 2 \times 10^{9}$ sperm $/ \mathrm{mL}$. Spermatic motility was subjectively analyzed using a phase contrast microscope (Olympus, Japan; 100x) and spermatic concentration in a Neubauer chamber (400x), after dilution of semen aliquots in saline formalin solution (1:400) (CBRA, 2013).

For cryopreservation, was used the protocol described by Silva et al. (2019), where the goat semen pools were diluted (1:9) in Tris buffer solution and centrifuged twice (3000 rpm; $10 \mathrm{~min}$ ). Then, the spermatozoa pellets were diluted in skimmedmilk based extender, to a concentration of $200 \times 10^{6} \mathrm{sperm} / \mathrm{mL}$, fractionated and treated, according to the experimental groups (G1=control, G2=20 $\mu \mathrm{M}$ Trolox and G3=40 $\mu \mathrm{M}$ Trolox).

The diluted semen was packaged in straws $(0.25 \mathrm{~mL})$ and frozen in an automated system (TK $3000 ®$ - TK Tecnologia em Congelação Ltda., Brazil). The cooling curve used showed a drop of $-0.25{ }^{\circ} \mathrm{C} / \mathrm{min}$ in temperature until reaching $5{ }^{\circ} \mathrm{C}$, at which the material remained for $120 \mathrm{~min}$ (stabilization time). Then the freezing curve was initiated, with a drop of $-20{ }^{\circ} \mathrm{C} / \mathrm{min}$, until reaching $-120^{\circ} \mathrm{C}$, when the straws were immersed and stored in liquid nitrogen $\left(-196{ }^{\circ} \mathrm{C}\right)$.

Regarding the ram semen pools, they were diluted in Tris-egg yolk extender (Silva et al., 2012), for the final concentration of $200 \times 10^{6}$ sperm $/ \mathrm{mL}$, fractionated and treated according to the experimental groups $(\mathrm{G} 1=\mathrm{control}, \mathrm{G} 2=20 \mu \mathrm{M}$ and $\mathrm{G} 3=40 \mu \mathrm{M}$ of Trolox). Subsequently, the samples were stored in straws $(0.25 \mathrm{~mL})$ and frozen in an automated system, as previously described for goat semen.

The evaluation of the lipid peroxidation, normally associated with sperm damages during cryopreservation (Aitken et al., 1993; Bollwein \& Bittner, 2018) and acting as an indicator of the male fertility (Colagar et al., 2013), was did dosing MDA (malondialdehyde) by HPLC according Candan \& Tuzmen (2008), with modifications. For this, work solutions were prepared and, previously to the lipoperoxidation analysis in semen samples, a standard curve was prepared with TEP. The TEP working solution (40 nmol/mL; $2 \mathrm{~mL}$ TEP stock solution, $50 \mathrm{~mL}$ sulfuric acid) was diluted in series using water to standard concentrations of $10,5,2.5,1.25$ and $0.625 \mathrm{nmol} / \mathrm{mL}$, and incubated for $2 \mathrm{~h}$ at room temperature.

To a volume of $500 \mu \mathrm{L}$ of each standard sample, $750 \mu \mathrm{L} \mathrm{H}_{3} \mathrm{PO}_{4}(440 \mathrm{mM})$ and $50 \mu \mathrm{L}$ TBA $(40 \mathrm{mM})$ were added, and the resulting mixtures heated for $1 \mathrm{~h}$ at $100{ }^{\circ} \mathrm{C}$ to promote the derivatization reaction. At room temperature, an aliquot $(500$ $\mu \mathrm{L}$ ) of these standards was mixed with $500 \mu \mathrm{L}$ of the precipitation reagent [MeOH:1 M NaOH (91:9)], filtered through a membrane filter $(0.22 \mu \mathrm{m})$ and evaluated. 
For the analysis of lipid peroxidation by HPLC in frozen semen, four semen straws of each experimental group and species were thawed in a water bath $\left(37^{\circ} \mathrm{C} / 30 \mathrm{~s}\right)$ and processed as described by Candan \& Tuzmen (2008), with modifications. In a cover glass tube, mixtures of $200 \mu \mathrm{L}$ semen, $750 \mu \mathrm{L} \mathrm{H} \mathrm{H}_{3} \mathrm{PO}_{4}(440 \mathrm{mM})$ and $50 \mu \mathrm{L}$ TBA $(40 \mathrm{mM})$ were heated for $1 \mathrm{~h}$ at $100{ }^{\circ} \mathrm{C}$. After reaching room temperature, $500 \mu \mathrm{L}$ was transferred to a microcentrifuge tube and added of $500 \mu \mathrm{L}$ precipitation reagent [MeOH: $1 \mathrm{M} \mathrm{NaOH}$ (91:9)]. The samples were centrifuged (13,000 rpm for $5 \mathrm{~min}$ ) and the supernatant was removed and filtered $(0.22 \mu \mathrm{m}$ membrane filter).

The chromatographic separations were performed using Rexchorm ODS column (150 mm x $4.6 \mathrm{~mm}$ x $5 \mu \mathrm{m})$ and Security Guard Catridge Holder guard column at $30{ }^{\circ} \mathrm{C}$, after injection of $400 \mu \mathrm{L}$ of each standard in the HPLC equipment (Shimadzu Prominence, model LC-20AT). Methanol (A) and potassium phosphate buffer solution (50 mM, pH=6.8, B) were used as a mobile phase (40:60), with a flow of $0.6 \mathrm{~mL} / \mathrm{min}$. The chromatograms were recorded at wavelength of $532 \mathrm{~nm}$ for 8 min, and the sample injection volume was $10 \mu \mathrm{L}$. All samples were prepared and analyzed in triplicate and the adduct concentrations expressed in $\mathrm{nmol} / \mathrm{mL}$.

The modified methodology of Partyka et al. (2011) was used to lipid peroxidation analysis, employing C11BODIPY ${ }^{581 / 591}$ fluorescent probe [4,4-difluoro-5-(4-phenyl-1,3-butadienyl)-4-bora-3a,4a-diaza-s-indacene-3-undecanoic acid; Invitrogen $^{\mathrm{TM}}$, Eugene, Oregon, USA]. Thawed semen samples were centrifuged (1500 rpm for $5 \mathrm{~min}$ ) twice in PBS (Buffered Saline Phosphate), resuspended in this with $1 \mu \mathrm{L}$ C11-BODIPY ${ }^{581 / 591}(2 \mathrm{mM})$ and incubated $\left(37^{\circ} \mathrm{C}\right.$ for $\left.30 \mathrm{~min}\right)$ in the dark. Subsequently, the samples were washed in PBS to remove the disconnect probe and analyzed by flow cytometry (flow cytometer BDFACSAria II; Becton Dickinson, EUA). The data were collected from BD FACSDivaTM Software (Becton Dickinson), where 10000 cells were evaluated and classified as oxidized, when green, or as non-oxidized, when red.

Regarding the study of plasma membrane integrity (PMi), parameter positively correlated with fertility (Lee et al., 2009) and most affected by semen cryopreservation (Castro et al., 2016), it was performed by double staining with carboxifluorescein diacetate (CFD) and propidium iodide (PI) (Silva et al., 2019). A total of 200 spermatozoa were evaluated under an epifluorescence microscope (Carl Zeiss, Germany; 400x) and classified as carriers of intact membrane, when stained in green, or damaged membrane, when stained in red.

The acrosome integrity, essential to the fertility (Fernandes \& Pimentel, 1997), was evaluated through fluoresceine isothiocyanate-conjugated peanut agglutinin (FITC-PNA) (Silva et al., 2019). A total of 200 spermatozoa per slide were analyzed under a fluorescence microscope (Carl Zeiss, Germany) and classified as having intact acrosome (Aci), when stained in green, or reacted acrosome (Acr), when stained in mixed green, without staining or stained only in the equatorial region of the sperm head.

For the study of sperm kinematics, significantly compromised with the cryopreservation process (Anand \& Yadav, 2016), an aliquot of semen was diluted in Tris solution (1:3) to reduce the cell concentration and the medium density, avoiding the cell superposition and facilitating the images capture. As Silva et al. (2019), the samples were evaluated under a phase contrast microscope (Eclipse 50i; Nikon, Japan; 100x), coupled with a Basler A312FC digital camera (Basler Vision Technologies, Germany), and the kinetic parameters analysis by the SCA software тм v 5.1 (Microptics, Spain). Were considered the total motility (TM, \%), progressive motility (PM, \%), linearity (LIN, \%), straight linearity (STR, \%) and oscillation index (WOB, \%), curvilinear velocity (VCL, $\mu \mathrm{m} / \mathrm{s}$ ), straight-line velocity (VSL, $\mu \mathrm{m} / \mathrm{s}$ ) and mean trajectory velocity (VAP, $\mu \mathrm{m} / \mathrm{s})$.

The statistical analyses were performed using GraphPad InStat (version 3.10, 2009). The data obtained to lipid peroxidation, plasma membrane integrity, acrosome integrity and sperm kinematic were tested for normality and homogeneity of variance by Kolmogorov-Smirnov method and Bartlett's test. Subsequently, these were submitted to analysis of variance (ANOVA), according to each species and experimental group, to determine the effects of the treatments and their interactions, 
considering significance of 5\%. When presented significance, Tukey-Kramer multiple comparison test was realized for mean comparisons. The results were expressed as means and standard deviation (means $\pm \mathrm{SD}$ ).

\section{Results}

The results demonstrated that the Trolox addition, at 20 or $40 \mu \mathrm{M}$ concentrations, to the goat and ram semen cryopreservation extender does not determine significant differences $(p>0.05)$ in the levels of MDA or in the percentage of cells marked with C11-BODIPY ${ }^{581 / 591}$, when compared to the control group (Table 1).

Table 1 - Malonaldehyde concentration $(\mathrm{nmol} / \mathrm{mL})$ and percentage (\%) of spermatozoa marked to peroxidation by $\mathrm{C} 11$ BODIPY581/591 fluorescent probe (mean \pm SD) in samples of goat and ram cryopreserved semen, with or without the addition of Trolox.

\begin{tabular}{cccc}
\hline Parameters & \multicolumn{3}{c}{ Experimental Groups } \\
\hline Coat & Control & Trolox 20 $\boldsymbol{\mu M}$ & Trolox 40 $\boldsymbol{\mu M}$ \\
\hline MDA (nmol/mL) & $0.2 \pm 0.1$ & $0.2 \pm 0.0$ & $0.2 \pm 0.1$ \\
Cells with LPO (\%) & $2.1 \pm 0.1$ & $2.1 \pm 0.0$ & $2.2 \pm 0.0$ \\
Ram & & & \\
MDA (nmol/mL) & $2.9 \pm 0.7$ & $2.9 \pm 0.8$ & $2.8 \pm 0.6$ \\
Cells with LPO $(\%)$ & $2.5 \pm 0.0$ & $2.4 \pm 0.0$ & $2.6 \pm 0.3$ \\
\hline
\end{tabular}

MDA: malondialdehyde, LPO: lipoperoxidation. Source: Authors.

Similarly, to the above exposed, no differences ( $p>0.05$ ) were observed between the experimental groups for sperm kinematics, plasma membrane integrity, and acrosome integrity of goat and ram semen, after freezing-thawing, in presence or absence of Trolox (Table 2). 
Table 2 - Kinetics parameters, plasma membrane integrity and acrosome integrity (mean \pm SD) of goat and ram cryopreserved sperm, with or without Trolox addition.

\begin{tabular}{|c|c|c|c|}
\hline \multirow[t]{2}{*}{ Spermatic Parameters } & \multicolumn{3}{|c|}{ Experimental Groups } \\
\hline & Control & Trolox $20 \mu \mathrm{M}$ & Trolox $40 \mu \mathrm{M}$ \\
\hline \multicolumn{4}{|l|}{ Goat } \\
\hline $\mathrm{TM}(\%)$ & $70.0 \pm 12.9$ & $70.4 \pm 5.6$ & $62.7 \pm 10.7$ \\
\hline PM (\%) & $26.0 \pm 2.8$ & $29.4 \pm 5.9$ & $29.0 \pm 7.2$ \\
\hline VCL $(\mu \mathrm{m} / \mathrm{s})$ & $87.0 \pm 8.4$ & $80.4 \pm 5.6$ & $88.1 \pm 13.1$ \\
\hline $\operatorname{VSL}(\mu \mathrm{m} / \mathrm{s})$ & $46.5 \pm 7.2$ & $45.0 \pm 4.9$ & $51.6 \pm 8.4$ \\
\hline $\operatorname{VAP}(\mu \mathrm{m} / \mathrm{s})$ & $61.2 \pm 7.8$ & $56.6 \pm 3.4$ & $63.9 \pm 10.8$ \\
\hline $\operatorname{LIN}(\%)$ & $53.6 \pm 8.7$ & $56.2 \pm 7.1$ & $58.6 \pm 5.5$ \\
\hline STR $(\%)$ & $75.8 \pm 7.4$ & $79.4 \pm 6.0$ & $80.8 \pm 3.9$ \\
\hline WBO $(\%)$ & $70.3 \pm 5.4$ & $70.5 \pm 3.7$ & $72.4 \pm 4.0$ \\
\hline $\operatorname{PMi}(\%)$ & $51.3 \pm 8.4$ & $58.3 \pm 9.0$ & $51.6 \pm 10.5$ \\
\hline Aci $(\%)$ & $86.7 \pm 3.7$ & $92.1 \pm 3.6$ & $90.6 \pm 1.4$ \\
\hline \multicolumn{4}{|l|}{ Ram } \\
\hline $\mathrm{TM}(\%)$ & $62.7 \pm 7.2$ & $66.0 \pm 10.6$ & $69.7 \pm 7.8$ \\
\hline $\mathrm{PM}(\%)$ & $32.8 \pm 4.6$ & $36.4 \pm 9.2$ & $33.1 \pm 6.2$ \\
\hline $\mathrm{VCL}(\mu \mathrm{m} / \mathrm{s})$ & $88.0 \pm 18.4$ & $85.3 \pm 12.6$ & $87.0 \pm 9.9$ \\
\hline $\mathrm{VSL}(\mu \mathrm{m} / \mathrm{s})$ & $63.4 \pm 14.2$ & $62.1 \pm 11.0$ & $58.7 \pm 9.2$ \\
\hline $\mathrm{VAP}(\mu \mathrm{m} / \mathrm{s})$ & $76.8 \pm 17.5$ & $74.7 \pm 12.5$ & $74.4 \pm 10.3$ \\
\hline LIN (\%) & $71.9 \pm 3.9$ & $72.6 \pm 3.8$ & $67.3 \pm 4.7$ \\
\hline $\operatorname{STR}(\%)$ & $82.6 \pm 3.2$ & $83.0 \pm 2.3$ & $78.7 \pm 3.3$ \\
\hline WBO $(\%)$ & $86.9 \pm 2.2$ & $87.4 \pm 2.4$ & $85.3 \pm 2.9$ \\
\hline $\operatorname{PMi}(\%)$ & $50.3 \pm 14.0$ & $58.2 \pm 6.9$ & $56.0 \pm 7.6$ \\
\hline $\operatorname{Aci}(\%)$ & $61.5 \pm 7.0$ & $64.5 \pm 6.5$ & $64.9 \pm 8.8$ \\
\hline
\end{tabular}

TM: total motility, PM: progressive motility, VCL: curvilinear velocity, VSL: straight-line velocity, VAP: average path velocity, LIN: linearity, STR: straightness, WBO: oscillating index, PMi: plasma membrane integrity, Aci: acrosome integrity. Source: Authors.

\section{Discussion}

High ROS levels in semen lead to lipid peroxidation, that is a process harmful to spermatozoa, which may contribute to low motility, morphology and sperm count (Colagar et al., 2013). In this sense, a negative correlation between oxidative stress and sperm motility has been described in ram (Peris et al., 2007). However, in the present study, there was no decline in motility, as well as in any other kinetic parameter, plasma membrane and acrosome integrity after cryopreservation, regardless of antioxidant addition ( 0,20 or $40 \mu \mathrm{M}$ of Trolox), being the total motility higher than $70 \%$ for goats and $60 \%$ for ram.

Based on the above exposed, is evident the absence of a protective effect of Trolox, in the concentrations studied, on the sperm of goats and ram. These findings corroborate with Sicherle et al. (2011) that did not observe a positive action of this agent at $100 \mu \mathrm{M}$, on ram semen, after thawing, except when lipid peroxidation was induced. Similarly, Cabrita et al. (2011) when using 0.1 and $0.5 \mathrm{mM}$ of $\alpha$-tocopherol for freezing fish sperm, did not find a better preservation of gametes kinetics, viability or DNA integrity. 
In opposition to the previous reports, Silva et al. (2013) showed that the Trolox addition at 60 or $120 \mu \mathrm{M}$ to the egg yolk medium improved the parameters of PM, VSL, VAP, LIN, WOB, STR and PMi. Similarly, Azawi \& Hussein, (2013) also saw improvement to plasma membrane integrity, but not to acrosome, for up to $120 \mathrm{~h}$ of refrigeration $\left(5^{\circ} \mathrm{C}\right)$ of ram sperm, added with $1 \mathrm{mg} / \mathrm{mL}$ of vitamin $\mathrm{E}$.

The absence of protective effect in relation to the antioxidant studied can be attributed to factors such as the dosedependent action (Aitken, 1995) once that, despite Silva et al. (2013) having used the same cryopreservation methodology of the present report, the antioxidant concentrations applied were higher. In addition, it is worth highlighting the specie-specific variation, and the composition of the medium to which the antioxidant is added (Guthrie \& Welch, 2007; Lecewicz et al., 2018; Silva et al., 2019).

The use of 20 and $40 \mu \mathrm{M}$ of Trolox did not reduce the concentrations of malonaldehyde present in cryopreserved semen of goats and ram, when compared to the control group. This fact also was observed by Sicherle et al. (2011) after the use of Trolox (100 $\mu \mathrm{M} / 10^{8}$ spermatozoa), during the process of ram semen frozen and thawed. On the other hand, inducing the lipid peroxidation with $0.24 \mathrm{nmol} \mathrm{FeSO}_{4}$, these authors verified that the antioxidant became efficient in reduce this harmful process (Sicherle et al., 2011). The same was observed by Maia et al. (2010), when using Trolox (50 $\mu \mathrm{M}$ Trolox/10 ${ }^{8}$ spermatozoa) for ram semen freezing, as well as by Cerolini et al. (2000), when added $\alpha$-tocopherol for boar semen refrigeration.

According to the above exposed, it is possible that the protective antioxidant effect of Trolox, beyond to be a dosedependent way, is evidenced only in situations of extreme stress, as is the case of lipoperoxidation induction (Partyka et al., 2011). The variability of results obtained after Trolox therapy may be justified by factors as the influence caused by the iron concentration in semen samples over the ROS production (Peris et al., 2007), the quantity and associations of antioxidants added and present in the semen, as well as the variations in the sperm membrane lipid composition (Guthrie \& Welch, 2007; Lecewicz et al., 2018).

\section{Conclusion}

It is concluded that Trolox $(20$ or $40 \mu \mathrm{M})$ does not favor the preservation of kinematic parameters, plasma membrane and acrosome integrity, as well as the reduction of lipid peroxidation degree in goat and ram sperm submitted to freezing. However, is important realize new investigations that consider a greater variety of antioxidant concentrations and correlated it with the specie and extender employed, as well as the induction or not of the lipid peroxidation.

\section{Acknowledgments}

The authors would like to thank the Fundação de Amparo à Ciência e Tecnologia do Estado de Pernambuco (FACEPE), for granting master's scholarships and financial support, together with the Conselho Nacional de Desenvolvimento Científico e Tecnológico (CNPq) and Conselho de Aperfeiçoamento de Pessoal de Nível Superior (CAPES).

\section{References}

Aitken, R. J., Harkiss, D., \& Buckingham, D. W. (1993). Analysis of lipid peroxidation mechanisms in human spermatozoa. Molecular Reproduction and Development, 35(3), 302-315. 10.1002/mrd.1080350313

Azawi, O. I., \& Hussein, E. K. (2013). Effect of vitamins C or E supplementation to Tris diluent on the semen quality of Awassi rams preserved at $5{ }^{\circ} \mathrm{C}$. Veterinary Research Forum, 4(3), 157-160. https://www.ncbi.nlm.nih.gov/pmc/articles/PMC4312374/pdf/vrf-4-157.pdf

Bicudo, S. D., Azevedo, H. C., Maia, S. M., Green, R. E., Rodello, L., \& Meira, C. (2007). Avanços na criopreservação do sêmen ovino visando sua aplicação em programas de inseminação artificial e em biotecnologias com embriões. Acta Scientiae Veterinariae, 35(3), 787-798. https://www.alice.cnptia.embrapa.br/alice/bitstream/doc/372377/1/Avancos0001.pdf 
Bollwein, H., \& Bittner, L. (2018). Impacts of oxidative stress on bovine sperm function and subsequent in vitro embryo development. Animal Reproduction, 15 (1), 703-710. 10.21451/1984-3143-AR2018-0041

Bucak, M.N., Atessahin, A., \& Yuce, A. (2008). Effect of antioxidants and oxidative stress parameters on ram semen after the freeze-thawing process. Small Ruminant Research, 75(2-3), 128-134. 10.1016/j.smallrumres.2007.09.002

Cabrita, E., Ma, S., Diogo, P., Martinez-paramo, S., Sarasquete, C., \& Dinis, M. T. (2011). The influence of certain aminoacids and vitamins on post-thaw fish sperm motility, viability and DNA fragmentation. Animal Reproduction Science, 125(1-4), 189-195. 10.1016/j.anireprosci.2011.03.003

Candan, N., \& Tuzmen, N. (2008). Very rapid quantification of malondialdehyde (MDA) in rat brain exposed to lead, aluminium and phenolic antioxidants by high-performance liquid chromatography - fluorescence detection. Neutotoxicology, 29(4), 709-713. 10.1016/j.neuro.2008.04.012

Castro, L.S., Hamilton, T. R. S., Mendes, C. M., Nichi, M., Barnabe, V. H., Visintin, J. A., \& Assumpção, M. E. O. A. (2016). Sperm cryodamage occurs after rapid freezing phase: flow cytometry approach and antioxidant enzymes activity at different stages of cryopreservation. Journal of Animal Science and Biotechnology, 7(17), 7-17. 10.1186/s40104-016-0076-x

CBRA - Colégio Brasileiro Reprodução Animal (2013). Manual para exame andrológico e avaliação de sêmen animal. (3a.ed.), (104 p.). Belo Horizonte: CBRA.

Cerolini, S., Maldijan, P., Surai, P., \& Noble, R. (2000). Viability susceptibility to peroxidation and fatty acid composition of boar semen during liquid storage. Animal Reproduction Science, 58 (1-2), 99-111. 10.1016/s0378-4320(99)00035-4

Colagar, A.H., Dermani, F. K., \& Jorsaraei, S. G. (2013). Antioxidants Levels in Astheno- and Oligoastheno- Teratospermic Men. Iranian Red Crescent Medical Journal, 15(9), 780-785. DOI: 10.5812/ircmj.6409

Fernandes, C. E., \& Pimentel, C. A. (1997). Anormalidades de acrossomo e fertilidade em um garanhão: relato de um caso. Ciência Rural, 27(2), 345-349. DOI: $10.1590 / \mathrm{S} 0103-84781997000200031$

Gangawar, C., Kharche, S. D., Kumar, S., \& Jindal, S. K. (2016). Cryopreservation of goat semen: status and prospects. Indian Journal of Small Ruminants, 22(1), 1-10. 10.5958/0973-9718.2016.00005.2

Guthrie, H. D., \& Welch, G.R . (2007). Use of fluorescence-activated flow cytometry to determine membrane lipid peroxidation during hypothermic liquid storage and freeze-thawing of viable boar sperm loaded with C11-BODIPY 581/591. Journal Animal Science, 85(1402-1411), 1402-1411. 10.2527/jas.2006787

Lecewicz, M., Strzezek, R., Kordan, W., \& Majewska, A. (2018). Effect of extender supplementation with low-molecular-weight antioxidants on selected quality parameters of cryopreserved canine spermatozoa. Journal of Veterinary Research, 62(2), 221-227. 10.2478/jvetres-2018-0032

Lee, H. L., Kim, S. H., Ji, D. B., \& Kim, Y. J. (2009). A comparative study of Sephadex, glass wool and Percoll separation techniques on sperm quality and IVF results for cryopreserved bovine semen. Journal of Veterinary Science, 10(3), 249-255. 10.4142/jvs.2009.10.3.249

Maia, M. S., Bicudo, S. D., Sicherle, C. C., Rodello, L., \& Gallego, I. C. S. (2010). Lipid peroxidation and generation of hydrogen peroxide in frozen-thawed ram semen cryopreserved in extenders with antioxidants. Animal Reproduction Science, 122(1-2), 118-123. 10.1016/j.anireprosci.2010.08.004

Minaei, M. B., Barbarestani, M., Nokoonam, S., Abdolvahabi, M. A., Takzare, N., Asadi, M. H., Hedayatpour, A., \& Amigi, F. (2012). Effect of Trolox addition to cryopreservation media on human sperm motility. Iranian Journal of Reproductive Medicine, 10(2), 99-104. https://www.ncbi.nlm.nih.gov/pmc/articles/PMC4163270/pdf/ijrm-10-099.pdf

Oliveira, M. E. F., Teixeira, P. P. M., \& Vicente, W. R. R. (2013). Biotécnicas reprodutivas em ovinos e caprinos. (305p). Med Vet.

Partyka, A., Lukaszewicz, E., Nizanski, W., \& Twardon, J. (2011). Detection of lipid peroxidation in frozen-thawed avian spermatozoa using C(11)BODIPY(581/591). Theriogenology, 75(9), 1623-1629. 10.1016/j.theriogenology.2011.01.002

Pena, F. J., Johanisson, A., Wallgren, M., \& Rodriguez Martinez, H. (2003). Antioxidant supplementation in vitro improves boar sperm motility and mitochondrial membrane potential after cryopreservation of different fractions of the ejaculate. Animal Reproduction Science, 78(1-2), 85-98. 10.1016/s03784320(03)00049-6

Peris, S. I., Bilodeau, J. F, Dufour, M., \& Bailey, J. L. (2007). Impact of cryopreservation and reactive oxygen species on DNA inetgrity, lipid peroxidation, and functional parameters in ram sperm. Molecular Reproduction and Development, 74(7), 878-892. 10.1002/mrd.20686

Sicherle, C. C., Maia, M. S., Bicudo, S. D., Rodello, L., \& Azevedo, H. C. (2011). Lipid peroxidation and generation of hydrogen peroxide in frozen-thawed ram semen supplemented with catalase or Trolox. Small Ruminant Research, 95(1-2), 144-149. 10.1016/j.smallrumres.2010.10.011

Silva, E. C. B., Arruda, L. C. P., Vieira, J. I. T, Soares, P. C., \& Guerra, M. M. P. (2019). (+)-Catechin and (-)-epigallocatechin gallate: are these promising antioxidant therapies for frozen goat semen? Arquivo Brasileiro de Medicina Veterinária e Zootecnia, 71(2), 521-528. 10.1519/1678-4162-10539

Silva, E. C. B., Cajueiro, J. F. P., Silva, S. V., Soares, P. C., \& Guerra, M. M. P. (2012). Effect of antioxidants resveratrol and quercetin on in vitro evaluation of frozen ram sperm. Theriogenology, 77(8), 1722-1726. 10.1016/j.theriogenology.2011.11.023

Silva, S. V., Soares, A. T., Batista, A. M., Almeida, F. C., Nunes, J. F., Peixoto, C. A., \& Guerra, M. M. P. (2013). Vitamin E (Trolox) addition to Tris-egg yolk extender preserves ram spermatozoon structure and kinematics after cryopreservation. Animal Reproduction Science, 137(1-2), 37-44. 10.1016/j.anireprosci.2012.12.002 
Research, Society and Development, v. 10, n. 5, e10310514764, 2021

(CC BY 4.0) | ISSN 2525-3409 | DOI: htttp://dx.doi.org/10.33448/rsd-v10i5.14764

Solihati, N., Rasad, S. D., Setiawan, R., Fozian, E. N., \& Wigiyanti, E. T. (2018). Semen Quality of Post-Thawed Local Ram's in Tris-Egg Yolk Extender with Different Glutathione Level. IOP Conference Series Earth and Environmental Science, 119(1), 12-34. 10.1088/1755-1315/119/1/012034

Taylor, K., Roberts, P., Sanders, K., \& Burton, P. (2009). Effect of antioxidant supplementation of cryopreservation medium on post-thaw integrity of human spermatozoa. Reproductive BioMedicine, 18(2), 184-189. 10.1016/S1472-6483(10)60254-4

Ugur, M.R., Abdelrahman, A. S., Evans, H. C., Gilmore, A. A., Hitit, M., Arifiantini, R. L., Purwantara, B., Kaya, A., \& Memili, E. (2019). Advances in cryopreservation of Bull Sperm. Frontiers in Veterinary Science, 6(268), 1-15. 10.3389/fvets.2019.00268

Zanella, E., Zanella, R., Poetini, M. R., Marques, M. G., Soares, J. C. M. \& Bondan, C. (2016). Oxidative Status of Boar Semen during Storage. American Journal of Biochemistry and Biotechnology, 12(2), 95-101. 10.3844/ajbbsp.2016.95.101 